\title{
Oromo Language
}

National Cancer Institute

\section{Source}

National Cancer Institute. Oromo Language. NCI Thesaurus. Code C154070.

An Afroasiatic language spoken in the Horn of Africa. 